\title{
Role for coronin 1 in mouse NK cell function
}

Vincent Sam Yong Tchang ${ }^{\mathrm{a}, \mathrm{b}, \mathrm{d}}$, Michael Stiess ${ }^{\mathrm{a}}$, Kerstin Siegmund ${ }^{\mathrm{a}, \mathrm{d}}$, Urs Karrer ${ }^{\mathrm{b}, \mathrm{c}^{*}}$ and Jean Pieters $^{\mathrm{a}, *}$

${ }^{\mathrm{a}}$ Biozentrum, University of Basel, ${ }^{\mathrm{b}}$ Division of Infectious Diseases and Hospital Epidemiology, University Hospital of Zurich, Ramistrasse 100, CH-8091 Zurich, Switzerland and ${ }^{\mathrm{c}}$ Department of Medicine, Cantonal Hospital of Winterthur, Brauerstrasse 15, CH-8401 Winterthur, Switzerland; ${ }^{\mathrm{d}}$ Present addresses: SAK, Bern, Switzerland (VSYT) and Department for Pharmacology and Genetics, Medical University of Innsbruck, Innsbruck, Austria (KS).

*: Corresponding author. Tel: +4161267 14 94; Fax: +416126721 48;

jean.pieters@unibas.ch

Short title: Coronin 1 and mouse NK cells

Key words: Coronin 1; NK cells; leukocyte activation

Abbreviations: VSV, vesicular stomatitis virus; ICS, intercellular cytokine staining 


\begin{abstract}
Coronin 1, a member of the evolutionary conserved WD repeat protein family is expressed in all leukocytes, but a role for coronin 1 in natural killer (NK) cell homeostasis and function remains unclear. Here, we have analyzed the number and functionality of NK cells in the presence and absence of coronin 1. In coronin 1-deficient mice, absolute NK cell numbers and phenotype were comparable to wild type mice in blood, spleen and liver. Following in vitro stimulation of the activating NK cell receptors NK1.1, NKp46, Ly49D and NKG2D, coronin 1-deficient NK cells were functional with respect to interferon- $\gamma$ production, degranulation and intracellular $\mathrm{Ca}^{2+}$ mobilization. Also, both wild type as well as coronin 1-deficient NK cells showed comparable cytotoxic activity. Furthermore, activation and functionality of NK cells following Vesicular Stomatitis Virus (VSV) infection was similar between wild type and coronin 1-deficient mice. Taken together these data suggest that coronin 1 is dispensable for mouse NK cell homeostasis and function.
\end{abstract}




\section{Introduction}

Natural killer (NK) cells play an important role for early control of viral infections as well as for anti-tumor defense. Hence, NK cell deficiency is associated with poor control of common herpes- and papilloma virus infections and increased occurrence of tumors [1-7]. NK cells sense their environment for low expression of major histocompatibility (MHC) class I molecules that are often down-regulated on virus infected or tumor cells and allows to escape $\mathrm{CD}^{+} \mathrm{T}$ cell-mediated immune control $[8,9]$. Upon viral infection, pro-inflammatory cytokines such as type I interferons are released by virus-infected cells as well as dendritic cells which result in NK cell activation and proliferation [2]. NK cell activation is tightly controlled by an arsenal of activating and inhibitory receptors [10-12]. Moreover, direct cellto-cell contact is needed to promote efficient NK cell activation and cytotoxic function $[10,13]$. Hence, whether NK cells become activated depends on the balance and strength of the activating and inhibitory signals.

Coronin 1 is a member of the highly conserved WD-repeat containing protein family of coronins. Coronin 1 is expressed in all leukocytes as well as a subset of neurons [14-17]. In leukocytes, coronin 1 regulates the survival of pathogenic mycobacteria within macrophages as well as naïve T cell homeostasis [14,18-20]. Whereas initially, coronin 1 was proposed to regulate $\mathrm{T}$ cell survival via regulation of F-actin dynamics, more recent work suggests that induction of F-actin alteration fails to induce apoptosis in T cells [20,21]. Instead, the capacity of coronin 1 to modulate mycobacterial survival and regulate $\mathrm{T}$ cell homeostasis has been linked to its function in modulating signal transduction including $\mathrm{Ca}^{2+} /$ calcineurin and phosphatidylinositol 3-kinase (PI3K)-dependent processes [22-25]. A role for coronin 1 in the activation of signal transduction in leukocytes is furthermore consistent with the recently described role of neuronally expressed coronin 1 in the modulation of the cAMP/protein kinase $\mathrm{A}$ and $\mathrm{Ca}^{2+} /$ calcineurin pathways in neurons as well as the role for the coronin 1 
homologue expressed in the slime mold Dictyostelium discoideum, coronin A, in the initiation of cAMP-dependent development $[15,26,27]$.

In B cells, dendritic cells and mast cells coronin 1 appears to be dispensable for their functionality [28-30]. Whether or not coronin 1 expressed in mouse NK cells performs any function in NK cell homeostasis and/or functionality is unclear. In this study, we report that coronin 1-deficient NK cells can be activated and are functional upon stimulation by antibodies directed against activating NK cell receptors. Moreover, NK cells from wild type and coronin 1-deficient mice displayed comparable cytotoxicity. In addition, NK cells from acutely VSV-infected coronin 1-deficient or wild type mice produced comparable amounts of interferon- $\gamma$. Taken together the results presented here suggest that coronin 1 is dispensable for NK cell survival, signaling and activation. 


\section{Material and methods}

Mice

C57BL/6 mice and the previously generated transgenic coronin 1-deficient mice [23] were bred in-house and kept under specific pathogen free (SPF) conditions. All animal experiments were conducted according to the regulations of the Cantonal Veterinary Office (Zurich/Basel, Switzerland). Six to twelve weeks old mice were used for all experiments.

\section{Antibodies}

Monoclonal antibodies for flow cytometry assays were purchased from BioLegend (Switzerland) if not indicated otherwise. The following antibodies were used: anti-NK1.1Alexa Fluor 647 (clone PK136), anti-CD3e-Pacific blue (clone 145-2C11), anti-interferon- $\gamma$ PE (clone XMG1.2), anti-CD107-Brilliat-Violet 421 (clone 1D4B), anti-CD122-PE (clone 5H4), PE Annexin V apoptosis detection kit (BD Pharmigen ${ }^{\mathrm{TM}}$, Cat. No. 559763). Antibodies for stimulation, blocking and $\mathrm{Ca}^{2+}$-flux analysis were purchased from BioLegend (Switzerland): LEAF purified and biotinylated anti-Ly49D (Clone 4E5), LEAF purified antiNKp46 (Clone 29A1.4), LEAF purified and biotinylated anti-NK1.1 (Clone PK136), LEAF purified anti-NKG2D (Clone A10) and LEAF purified anti-CD16/32 (Clone 93).

\section{Virus}

Virus was provided by Prof A. Oxenius (ETH Zurich, Switzerland). VSV (serotype Indiana) was propagated on BHK-21 cells as previously described [31]. $5 \times 10^{5} \mathrm{PFU}-5 \times 10^{6} \mathrm{PFU}$ of virus was used to infect mice intravenously (i.v.) via the tail vein.

\section{Lymphocytes isolation from the liver and spleen}

Cell isolation was essentially performed as described [32]; in brief, mice were euthanized with high percentage of $\mathrm{CO}_{2}$. After perfusion via the right heart ventricle (with 5-10 $\mathrm{ml}$ ice 
cold PBS) to remove all contaminating blood from the organs, the liver was harvested, and dissected into small pieces. Digestion was performed with $3 \mathrm{ml}$ RPMI (Gibco) supplemented with $2.4 \mathrm{mg} / \mathrm{ml}$ Collagenase (Gibco, Cat. No. 17100-017), $0.2 \mathrm{mg} / \mathrm{ml}$ DNase I (Roche, Cat. No. 1284932 ) and $10 \%$ FCS for 20 minutes at $37^{\circ} \mathrm{C}, 5 \% \mathrm{CO}_{2}$. Tissue samples were then gently disintegrated by pulling them through an $18 \mathrm{G}$ needle and additionally incubated in 2 $\mathrm{ml}$ of digestion medium for $20 \mathrm{~min}$. Subsequently, cell suspensions were smashed through a $70 \mu \mathrm{m}$ cell strainer (BD, Falcon) and washed twice with PBS. Samples were resuspended in 90\% isotonic Percoll and overlaid with 37\% Percoll and layered with PBS containing 30\% Percoll (Amersham Biosciences Europe GmbH; Cat. No. 17-0891-02) and centrifuged (800 $x g$ ) for $30 \mathrm{~min}$ at $4^{\circ} \mathrm{C}$. Lymphocytes were collected from the interphase and washed twice with RPMI, counted and resuspended in RPMI containing 10\% FCS, 100 units penicillinstreptomycin and $2 \mathrm{mM} \mathrm{L-glutamine} \mathrm{for} \mathrm{further} \mathrm{analysis.} \mathrm{Single} \mathrm{cell} \mathrm{suspensions} \mathrm{of} \mathrm{spleen}$ were produced by gently smashing the organ trough a grid of stainless steel. Depending on the experiment, erythrocytes were lysed by incubation in $1 \mathrm{ml} \mathrm{ACK}$ buffer $\left(155 \mathrm{mM} \mathrm{NH}_{4} \mathrm{Cl}, 10\right.$ $\mathrm{mM} \mathrm{KHCO} 2,0.1 \mathrm{mM}$ EDTA, $\mathrm{pH} 7.4$ ) for $3 \mathrm{~min}$ at $4{ }^{\circ} \mathrm{C}$. Viable cells were counted by trypan blue exclusion using a Neubauer counting chamber.

\section{NK cell enrichment from spleen}

Splenocytes were used to sort untouched NK cells using a NK cell enrichment kit (Stemcell technologies, EasySep ${ }^{\mathrm{TM}}$ Mouse NK Cell Enrichment Kit, Cat. No. 19755). NK cell were enriched according to the manufactures protocol and viable cells were counted by trypan blue exclusion using a Neubauer counting chamber.

\section{NK cell stimulation}

Maxi-sorp 96 well plates (Nunc; Cat. No. 439454) were coated at $4^{\circ} \mathrm{C}$ over night with antiNK1.1 $(5 \mu \mathrm{g} / \mathrm{ml})$, anti-NKp46 (5 $\mu \mathrm{g} / \mathrm{ml})$, anti-Ly49D $(5 \mu \mathrm{g} / \mathrm{ml})$ or anti-NKG2D $(10 \mu \mathrm{g} / \mathrm{ml})$ 
antibodies in $200 \mu \mathrm{l}$ carbonate buffer $\left(\mathrm{Na}_{2} \mathrm{CO}_{3}(29 \mathrm{mM}), \mathrm{NaHCO}_{3}(71 \mathrm{mM}), \mathrm{pH} 9.5\right)$. The next day, plates were washed twice with PBS and 0.5-1 x $10^{6}$ splenocytes in $200 \mu 1$ RPMI, $10 \%$ FCS, $10 \mathrm{mM}$ HEPES and $50 \mu \mathrm{M} \beta$-mercaptoethanol were added to the wells in the presence of brefeldin A or $1 \mu \mathrm{g}$ anti-CD107a-Brilliant Violet 421 . Cells were cultured at $37^{\circ} \mathrm{C}$ for 4.5 hours prior staining for NK1.1, CD3 $\varepsilon$ and interferon- $\gamma$.

\section{Immunofluorescence staining and analysis}

Unspecific binding of fluorochrome-conjugated antibodies to Fc receptors was blocked by incubation anti-CD16/32 for 5 min at $4^{\circ} \mathrm{C}$ prior surface staining. Fluorochrome-conjugated monoclonal antibodies were added to the samples for 20 min at $4{ }^{\circ} \mathrm{C}$. After a washing step, cells were re-suspended in $200 \mu \mathrm{l}$ MACS buffer for analysis (PBS, 5 mM EDTA, 2\% FCS). Samples were analyzed with a 6 or 8 color BD FACS Canto II Flow Cytometer using FACS Diva software. The data were analyzed with Flow-Jo version 7.5.2 (Tree Star Inc., Ashland, USA).

\section{Immunofluorescence microscopy}

Enriched NK cells $\left(3 \times 10^{5}\right)$ from spleen were allowed to adhere to poly-L-lysine coated, 10well Teflon-surrounded glass slides (Polysciences) for $60 \mathrm{~min}$ at $37^{\circ} \mathrm{C}, 5 \% \mathrm{CO}_{2}$. Slides were washed three times with PBS and fixed for 15 min with 3\% paraformaldehyde at room temperature and then blocked and permeabilized for $60 \mathrm{~min}$ in PBS, 5\% FBS, $0.1 \%$ TritonX100. The cells were then stained for $120 \mathrm{~min}$ at $37^{\circ} \mathrm{C}$ with antibodies to mouse-anti-mouse actin (Chemicon) and rabbit-anti-mouse coronin-1 (1002) [33]. Cells were subsequently washed with PBS and stained with secondary antibodies (goat anti-mouse-Alexa Fluor 637, goat anti-rabbit-Alexa Fluor 568; 1:200 each) for $60 \mathrm{~min}$ at $37^{\circ} \mathrm{C}$. Slides were washed five times with PBS and mounted with ProLong ${ }^{\circledR}$ Gold Antifade Reagent (Invitrogen, Cat. No. 
P36934). Slides were analyzed using a LSM510 Meta confocal laser scanning microscope (Zeiss) and the corresponding software.

\section{SDS-PAGE and Western Blotting}

Enriched NK cells $\left(1 \times 10^{6}\right)$ from spleen were lysed in $200 \mu$ lysis buffer $(50 \mathrm{mM}$ Tris-HCl (pH 7.5), 137 mM NaCl, 2 mM EDTA, 10\% Glycerol, 1\% Triton X-100, 1 mM PMSF, $1 \mathrm{X}$ Protein inhibitor cocktail (Roche, Complete Protease Inhibitor Cocktail) for $15 \mathrm{~min}$ on ice. Nuclei and unbroken cells were sedimented by centrifugation for $10 \mathrm{~min}$ at $15^{\prime} 000 \mathrm{rpm}, 4^{\circ} \mathrm{C}$. $80 \mu 1$ supernatant was mixed with $20 \mu 15 \mathrm{X}$ sample buffer (250 mM TrisHCl (pH6.8), 10\% SDS, 30\% Glycerol, 5\% $\beta$-mercaptoethanol, $0.02 \%$ bromophenol blue) and boiled for 5 min at $95^{\circ} \mathrm{C} .20 \mu \mathrm{l}$ of the samples were then separated on a $10 \%$ SDS-PAGE gel and transferred onto nitrocellulose membrane (Amersham Biosciences) and blotted against anti-actin (ChemiCon) and anti-coronin 1 (1002) serum [33].

\section{Scanning electronic microscopy}

Enriched NK cells from spleen were expanded with IL-15 $(10 \mathrm{ng} / \mathrm{ml})$ for 7 days by replacing the medium every second day. NK cells were seeded on poly-L-lysine treated $12 \mathrm{~mm}$ coverslips at a density of $5 \times 10^{4}$ cells at let adhere for $45 \mathrm{~min}$ at $37{ }^{\circ} \mathrm{C}, 5 \% \mathrm{CO}_{2}$. Cells were washed with ice-cold PBS and fixed with $2.5 \%$ glutaraldehyde (Sigma). Cells were subsequently processed for scanning electron microscopic analysis using the critical point drying technique [34] followed by analysis using a Phillips XL 30 ESEM.

\section{Intracellular cytokine staining}

Cells (lymphocytes, splenocytes, at $5 \times 10^{5}-2 \times 10^{6}$ ) were resuspended in $200 \mu 1 \mathrm{RPMI}$ supplemented with 10\% FCS. RPMI/10\% FCS (200 $\mu$ l) containing brefeldin A ( $20 \mu \mathrm{g} / \mathrm{ml})$ if not indicated else, was added to the cells. Depending on the experiment $1 \mu \mathrm{g}$ of fluorescent 
dye-conjugated anti-mouse CD107a antibody was added to the stimulation. Cells were incubated for $4.5-6$ hours at $37^{\circ} \mathrm{C}, 5 \% \mathrm{CO}_{2}$. Cells were washed with FACS-buffer (PBS, $2 \%$ FCS, $5 \mathrm{mM}$ EDTA, $0.05 \% \mathrm{NaN}_{3}$ ) and treated prior surface staining for $5 \mathrm{~min}$ at $4^{\circ} \mathrm{C}$ with a blocking anti-mouse CD16/32 antibody. Cells were subsequently stained for surface marker for 20-30 min at $4{ }^{\circ} \mathrm{C}$ and fixed with $2 \%$ PFA in FACS buffer. For interferon- $\gamma$ staining cells were permeabilized with $0.5 \%$ saponin in FACS buffer for 10 min at room temperature in the dark prior to intracellular staining $\left(30 \mathrm{~min}\right.$ at $\left.4^{\circ} \mathrm{C}\right)$. After washing, samples were analyzed using a 6-8 color BD FACS Canto II Flow Cytometer and Flowjo version 7.5.2.

\section{$\mathrm{Ca}^{2+}$ mobilization measurements in $\mathrm{NK}$ cells}

Enriched NK cells from spleen were loaded in RPMI 1640 (Invitrogen) without phenol red supplemented with $2 \mathrm{mM}$ glutamine and $10 \%$ FBS for 30 minutes at $37{ }^{\circ} \mathrm{C}$ with $4 \mu \mathrm{M}$ Fluo-4 and $10 \mu \mathrm{M}$ FuraRed (both Invitrogen) in the presence of Pluronic F-127 (Invitrogen). Cells were washed with medium, resuspended in $300 \mu \mathrm{L}$ medium, incubated for 5 minutes at $37^{\circ} \mathrm{C}$ and analyzed by flow cytometry (FACS Canto II, BD Biosciences). After 30 seconds baseline recording, $5 \mu$ l of biotinylated anti-NK1.1 mAB $(0.5 \mathrm{mg} / \mathrm{ml}$ in PBS, clone PK136) or antiLy49D mAB $(0.5 \mathrm{mg} / \mathrm{ml}$ in PBS, clone 4E5) was added and 60 seconds later $5 \mu \mathrm{l}$ of streptavidin was added (1 mg/ml in PBS; Sigma). Streptavidin only served as a negative control. Data were analyzed with FlowJo software. NK cells were gated on forward/side scatter plots. The ratio between the mean fluorescence intensity of Fluo-4 (PE channel) and FuraRed (PerCP channel) was calculated and plotted as a function of time. The 30 second baseline before antibody addition was used to allow normalization between the recordings and maximum increase of intracellular $\mathrm{Ca}^{2+}$ was plotted.

\footnotetext{
${ }^{51}$ Cr-cytotoxic assay
} 
Freshly isolated splenocytes or purified NK cells from spleen were either directly used (according to the indicated E:T ratio) for the cytotoxic assay or were treated prior to the assay for 20-22 hours with IL-15 (10 ng/ml) or medium alone in a round bottom 96-well cell culture microtiterplate.YAC-1 cells were cultured in RPMI supplemented with 10\% FCS and 200 mM L-glutamine. YAC- 1 cells $\left(2 \times 10^{7}\right)$ were loaded with $300 \mu \mathrm{Ci} \mathrm{Na}{ }^{51} \mathrm{CrO}_{4}(1 \mathrm{mCi} / \mathrm{ml}$ in PBS, Hartmann Analytic) for 90 min on a $37^{\circ} \mathrm{C}$ warm thermoshaker. YAC-1 cells were subsequently washed twice with PBS and resuspended at a concentration of $5 \times 10^{5}$ cells $/ \mathrm{ml}$ RPMI, $10 \%$ FCS and used as target cells. YAC- 1 cell suspension $\left(5 \times 10^{4}\right.$ cells; $\left.100 \mu 1\right)$ was then added to the pre-titrated splenocytes to obtain the indicated effector:target ratio. The cell mixture was then incubated for 4.5 hours at $37^{\circ} \mathrm{C}, 5 \% \mathrm{CO}_{2}$. Plates were centrifuged for $5 \mathrm{~min}$ at $500 x g$ and $40 \mu \mathrm{l}$ of supernatant was then transferred and mixed with $200 \mu 1$ liquid scintillator solution (Microscint 40, Perkin Elmer, Cat. No. 60136 41). CPM was then counted in a Packard TopCount Microplate scintillation counter (Model C9906, Packard). Specific cell lysis was calculated as follow: (experimental release - spontaneous release) / (maximum release - spontaneous release). Spontaneous release was between 11 and $16 \%$ of maximum release.

\section{NK cell survival}

Freshly isolated splenocytes or purified NK cells were cultured in the presence of IL-15 (10 $\mathrm{ng} / \mathrm{ml}$ ) or medium alone (RPMI; $10 \% \mathrm{FCS}, 200 \mathrm{mM} \mathrm{L}$-Glutamine) at $37^{\circ} \mathrm{C}, 5 \% \mathrm{CO}_{2}$ for 4 and 24 hours. At the indicated time points, cells were harvested, stained for CD3E, NK1.1, and 7AAD. Cells were counted by adding counting beads prior to FACS analysis purchased from Invitrogen (CountBright ${ }^{\mathrm{TM}}$ Absolute Counting Beads, Cat. No. C36950). Cells were then analyzed using a BD FACScanto II Flow Cytometer using FACS Diva software. The data were analyzed with Flowjo version 7.5.2. 
Statistical Analysis

Non-parametric two-tailed Mann-Whitney t-test was used for group comparisons using Graph Pad Prism (GraphPad Software, La Jolla, CA). The p-values are indicated in the figure legends. 


\section{Results}

NK cell numbers and phenotype in the presence and absence of coronin 1

To analyze the consequences of coronin 1 deletion for the NK cell population, we first compared the frequencies and absolute numbers of NK-cells in blood, spleen and liver of coronin 1-deficient and wild type mice by flow cytometry after staining for CD3 and the NK cell marker NK1.1 (Figure 1). We found that coronin 1-deficient mice showed significantly increased NK cell frequencies in all organs tested compared to wild-type mice (Figure 1A, B). However, absolute NK cell numbers were similar in spleen and blood. In contrast, a twofold increased NK cell number were observed in livers of coronin 1-deficient mice (Figure 1C), possibly as a result of T cell lymphopenia [18-22].

Next, we enriched NK cells from the spleen of wild-type and coronin 1-deficient mice to analyze the morphology of NK cells and the distribution and expression of coronin 1 and CD122, the $\beta$-chain of the IL-15 (and IL-2) receptor, given the importance of IL-15 for NK cell survival and function [35] (Figure 2). The efficiency of NK cell enrichment by negative selection was found to be similar for both wild-type and coronin 1-deficient NK cells (Figure 2A, please note that coronin 1-deficient mice express enhanced green fluorescent protein (EGFP) driven by the coronin 1 promoter). Analysis of coronin 1 expression by immunoblotting of NK cell lysates obtained from either wild type or coronin 1-deficient NK cells revealed that coronin 1 is expressed in wild-type NK cells, but is absent in NK cells of coronin 1-deficient mice (Figure 2B).

To analyze the effect of coronin 1 deletion on the morphological appearance of NK cells, NK cells were purified from either wild type or coronin 1-deficient mice, mixed in a 1:1 ratio, fixed and stained using anti-coronin 1 and anti-actin antibodies. As shown in Figure 2C, wild type (GFP-negative) and coronin 1-deficient (GFP-positive) NK cells were indistinguishable 
as observed by bright field microscopy or actin staining. Moreover, CD122 expression was similar between wild-type and coronin 1-deficient NK cells, both regarding the frequency of CD122 expressing NK cells (Figure 2D) as well as the mean fluorescence intensity (MFI) of CD122 (Figure 2E). From these results we conclude that NK cell numbers, their morphology and CD122 expression are not affected by the absence of coronin 1.

NK cell receptor stimulation and NK cell activation in the presence and absence of coronin 1 NK cells have an arsenal of activating (including NK1.1, NKp46, Ly49D, NKG2D) and inhibitory (such as Ly49a, c, e, f, g, i) receptors which signal through non-covalently bound

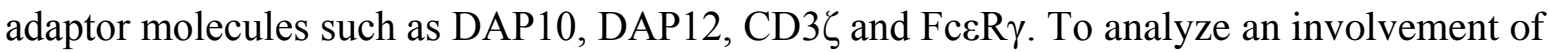
coronin 1 in activating NK cell receptor signaling, NK cells were stimulated by plate bound

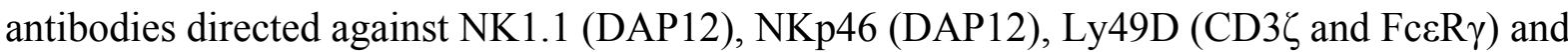
NKG2D (DAP10) (Figure 3). Thereafter, as a readout of activation, interferon- $\gamma$ or CD107a expression (as a surrogate for degranulation) was analyzed by flow cytometry (Figure 3). The frequencies of IFN $\gamma$ - or CD107a-positive NK cells were similar in coronin 1 and wild type mice after stimulation via NK1.1, NKp46 and NKG2D (Figure 3B-E), whereas an increased frequency of interferon- $\gamma$ producing NK cells after stimulation via Ly49D in coronin 1deficient mice was found (Figure 3B).

Since stimulation of ex vivo isolated NK cells via NKG2D did not induce any significant IFN $\gamma$-production or degranulation (Fig. 3C and E, left panels), splenocytes were pre-activated in vitro with IL-2 for $20 \mathrm{~h}$ and then stimulated with plate-bound anti-NKG2D (Fig. 3C and E, right panels). While IFN $\gamma$-production was similar between wild type and coronin 1-deficient NK cells, we found a slight reduction of CD107a-internalization in coronin 1-deficient NK cells. In accordance with these data, calcium mobilization was similar in both wild type as well as coronin 1-deficient NK cells after stimulation with anti-NK1.1 or Ly49D 
(supplementary Figure 1). While the reason for the elevated IFN- $\gamma$ production upon Ly49D stimulation remain to be analyzed, coronin 1-deficiency appears to have no significant influence on the activation of NK cells by plate bound antibodies directed against NK1.1, NKp46 and NKG2D.

Cytotoxic activity of NK cells against YAC-1 cells in the presence and absence of coronin 1 We reasoned that the capacity of coronin 1-deficient NK cells to produce interferon- $\gamma$ and to degranulate does not necessary reflect their cytotoxic potential. Therefore, we investigated whether coronin 1-deficient NK cells were able to induce cytotoxicity in the MHC class I negative tumor cell line YAC-1 by a classical ${ }^{51}$ Cr-release assay. As shown in Figure 4, splenocytes from wild-type and coronin 1-deficient mice were equally effective to lyse YAC1 cells. In addition, co-cultivation of YAC-1 cells with either wild type or coronin 1-deficient NK cells led to comparable interferon- $\gamma$ production (data not shown). From these results we conclude that NK cell cytotoxicity was not impaired in the absence of coronin 1.

\section{Ex vivo survival of wild-type and coronin 1-deficient NK cells}

In naïve T cells, coronin 1 is essential to provide pro-survival signals to allow $\mathrm{T}$ cell survival in peripheral immune organs [18-22]. To analyze a role for coronin 1 in ex vivo survival of NK cells, NK cells were purified and expanded for 21 days in the presence of interleukin-15. As shown in Figure 5A, both wild type as well as coronin 1-deficient NK cells expanded similarly in vitro. To analyze the morphology of wild type and coronin 1-deficient NK cells, we expanded enriched NK cells in vitro in the presence of interleukin-15 for seven days. Analysis by scanning electron microscopy failed to reveal any morphological differences between wild type and coronin 1-deficient NK cells (Figure 5B).To investigate whether in 
vitro-activated coronin 1-deficient NK cells were functional, NK cells were cultured in the presence or absence of interleukin-15 for $20-22$ hours and their ability to induce target cell lysis was then analyzed in a standard 4.5 hours Cr-51 release assay using YAC-1 as target cells. NK cells from both wild type and coronin 1-deficient mice, cultured in medium only, where not viable at this time point and failed to induce cytotoxicity (Fig. 5C, mock), NK cells from both wild type and coronin 1-deficient mice induced a similar and strong cytotoxicity when cultured in the presence of interleukin-15 (Fig. 5C, $I L-15$ ). Together these data suggest that coronin 1 is dispensable for IL-15-dependent NK cell survival, cytotoxic activity and proliferation in vitro.

\section{NK cell immune response to VSV in wild type and coronin 1-deficient mice}

To analyze a role for coronin 1 in NK cell responses upon a viral infection in vivo, wild type and coronin 1-deficient mice were infected with Vesicular Stomatitis Virus (VSV) intravenously. Forty-eight hours post infection, NK cell number and functionality from spleen and liver was analyzed by flow cytometry (Figure 6A). VSV-infection resulted in a slight decrease of total NK cells numbers in the spleen but not in the liver of both wild type and coronin 1-deficient mice (Figure 6B). However, the frequency and total number of IFN $\gamma$ producing activated NK-cells was similarly increased after VSV infection in both wild type and coronin 1-deficient mice (Figure 6C,D). These data suggest that coronin 1 deletion does not affect interferon- $\gamma$ production of NK cells after VSV infection. 


\section{Discussion}

Coronin 1 is a member of the WD repeat protein family of coronins that is highly expressed in leukocytes. Whereas coronin 1 is essential for naïve $\mathrm{T}$ cell homeostasis in mice and human [17-20,22] the role for coronin 1 in other leukocytes remains unclear [17,23,28-30,36,37]. Here, we have investigated the number, phenotype and functionality of NK cells. Although NK cell frequencies were increased in blood, spleen and liver of coronin 1-deficient mice, this was most likely due to T cell lymphopenia since total NK cell numbers (blood, spleen) or about twofold increased (liver) in the absence of coronin 1 . These findings are consistent with normal NK cell numbers present in the blood of human individuals lacking coronin 1 expression [35,38]. Thus, as is the case for B cells, macrophages, neutrophils and mast cells, coronin 1 appears to be largely dispensable for mouse NK homeostasis and function.

Activating signaling pathways in NK cells have strong similarities with T cell receptor signaling $[10,12,39]$. The different activating receptors (e.g. NK1.1, NKp46, Ly49D and NKG2D) transmit their signal via their specific ITAM containing adaptor molecules (DAP12,

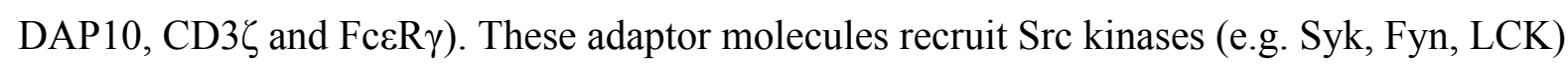
and initiate, upon activation, a downstream phosphorylation cascade, which depends on PLC $\gamma$ and $\mathrm{PI} 3 \mathrm{~K}$, resulting in intracellular $\mathrm{Ca}^{2+}$ release, calcineurin activation and transcription factor translocation to the nucleus $[4,10,12,40,41]$. Given these parallels between NK cell and T cell signaling as well as the importance of coronin 1 in activating the $\mathrm{Ca}^{2+} /$ calcineurin pathway in T cells $[17,18,22]$, we investigated whether coronin 1 is involved in NK cell survival and/or functionality. As shown here, NK cells lacking coronin 1 became similarly activated compared to wild type cells after stimulation with antibodies directed against several activating receptors that use different signaling adaptor molecules including DAP 10, DAP 12 or FceRI $\gamma[10,13]$. Both interferon- $\gamma$ production and degranulation were efficiently triggered in coronin 1-deficient NK cells, demonstrating that activating NK cell receptor signaling is 
not impaired in the absence of coronin 1. In addition, NK cells from wild-type and coronin 1deficient mice were able to lyse YAC-1 tumor cells to a similar extend suggesting a full induction of the cytotoxic machinery in a coronin 1-independent manner.

In naïve T cells, coronin 1 deletion results in their apoptosis due to a lack of an appropriate survival signal through the T cell receptor [21]. In NK cells, as in other leukocytes such as macrophages, neutrophils and mast cells [22,23,30,36], coronin 1 appears to be dispensable for cell survival in vivo and in vitro as judged by a similar capacity for expansion in the presence of interleukin-15. Furthermore, we could not observe any difference in the morphology of NK cells from wild type and coronin 1-deficient mice ex vivo or after in vitro expansion in interleukin-15-containing medium. These results suggest that IL-15-driven expansion and differentiation of NK cells is independent of coronin 1. In accordance with the results described here, a recent study reported that in human NK cells the absence of coronin 1 results in normal interferon- $\gamma$ production, activation receptor signaling and $\mathrm{Ca}^{2+}$ mobilization are not altered [42]. These authors do however describe a requirement for coronin 1 in cytolytic activity of human NK cells in contrast to the absence of a role for coronin 1 in cytolysis described here. Whether or not this discrepancy is due to speciesspecific differences or the exact cytolysis assay employed remains to be analyzed. Although the here reported results are consistent with the absence of a role for coronin 1 during VSV infection in mice, we cannot exclude that coronin 1 may play some role in particular NK cell subtypes. Also, as we have focused on the in vitro analysis on activating NK cell receptors, a potential role for coronin 1 in expression, signal transduction or functionality of inhibitory NK cell receptors remains to be analyzed. Furthermore, although the in vivo data on NK cell activity exclude a fundamental role of coronin 1 for NK-cell activity after VSV-infection, a role for coronin 1 in other viral infections, which require NKcell activity for early viral containment, remains to be analyzed. Finally, besides coronin 1 
there are several other coronin homologous that are expressed in leukocytes, and therefore it cannot be excluded that one or more of these coronin molecules are functionally redundant with coronin 1 .

In conclusion, the data presented here suggest that NK functionality is largely independent on the presence of coronin 1. Whether or not in NK cells, a function for coronin 1 is compensated for by the presence of other members of the coronin protein family or has become redundant because of compensatory (co) stimulatory mechanisms, as is for example the case for B cell activation [28] may be the subject of further studies.

\section{Acknowledgement}

We would like to thank Somdeb BoseDasGupta and the Center for Microscopy, University of Basel for electron microscopy, the members of the research group of Prof. Annette Oxenius (ETH Zurich, Switzerland) for invaluable discussions and sharing of reagents, Lea Häberli for expert technical assistance and PD Dr. Annelies Zinkernagel and Prof. Dr. med. Nicolas Müller for providing laboratory space and general support. Michael Stiess is a recipient of an HFSP Fellowship as well as an EMBO Long Term Fellowship. This work was further supported by the Canton of Basel, by the Swiss National Science Foundation to UK (grant PP0033-110737) and JP (31003A_146463), the Gebert Rueff Foundation, the Heuberg Foundation (Zürich), by the Aetas Foundation (Geneva) and by the Promedica Foundation (Chur; all from Switzerland) and by the FWF Austrian Science Fund ('Lise-Meitner" M1636-B23 to KS). A patent related to this work have been filed (WO2007110385A2) by the University of Basel. 


\section{References}

[1] Andoniou CE, Andrews DM, Degli-Esposti MA. Natural killer cells in viral infection: more than just killers. Immunol Rev 2006;214:239-250.

[2] Biron CA, Nguyen KB, Pien GC, Cousens LP, Salazar-Mather TP. Natural killer cells in antiviral defense: function and regulation by innate cytokines. Annu Rev Immunol 1999;17:189-220.

[3] Kagi D, Seiler P, Pavlovic J, Ledermann B, Burki K, Zinkernagel RM, et al. The roles of perforin- and Fas-dependent cytotoxicity in protection against cytopathic and noncytopathic viruses. Eur J Immunol 1995;25:3256-3262.

[4] Smyth MJ, Cretney E, Kelly JM, Westwood JA, Street SE, Yagita H, et al. Activation of NK cell cytotoxicity. Mol Immunol 2005;42:501-510.

[5] Vidal SM, Malo D, Vogan K, Skamene E, Gros P. Natural resistance to infection with intracellular parasites: isolation of a candidate for Bcg. Cell 1993;73:469-485.

[6] Zamai L, Ponti C, Mirandola P, Gobbi G, Papa S, Galeotti L, et al. NK cells and cancer. J Immunol 2007;178:4011-4016.

[7] Orange JS. Natural killer cell deficiency. J Allergy Clin Immunol 2013;132:515-525; quiz 526.

[8] Sentman CL, Olsson MY, Karre K. Missing self recognition by natural killer cells in MHC class I transgenic mice. A 'receptor calibration' model for how effector cells adapt to self. Semin Immunol 1995;7:109-119.

[9] Ljunggren HG, Karre K. In search of the 'missing self': MHC molecules and NK cell recognition [see comments]. Immunol Today 1990;11:237-244.

[10] Lanier LL. Up on the tightrope: natural killer cell activation and inhibition. Nat Immunol 2008;9:495-502.

[11] Colucci F, Schweighoffer E, Tomasello E, Turner M, Ortaldo JR, Vivier E, et al. Natural cytotoxicity uncoupled from the Syk and ZAP-70 intracellular kinases. Nat Immunol 2002;3:288-294.

[12] Watzl C, Long EO. Signal transduction during activation and inhibition of natural killer cells. Curr Protoc Immunol 2010; Chapter 11:Unit 11 19B.

[13] Colonna M. Natural killer cell receptors specific for MHC class I molecules. Curr Op Immunol 1996;8:101-109.

[14] Ferrari G, Langen H, Naito M, Pieters J. A coat protein on phagosomes involved in the intracellular survival of mycobacteria. Cell 1999;97:435-447.

[15] Jayachandran R, Liu X, Bosedasgupta S, Muller P, Zhang CL, Moshous D, et al. Coronin 1 Regulates Cognition and Behavior through Modulation of cAMP/Protein Kinase A Signaling. PLoS Biol 2014;12:e1001820.

[16] Okumura M, Kung C, Wong S, Rodgers M, Thomas ML. Definition of family of coroninrelated proteins conserved between humans and mice: close genetic linkage between coronin-2 and CD45-associated protein. DNA Cell Biol 1998;17:779-787.

[17] Pieters J, Muller P, Jayachandran R. On guard: coronin proteins in innate and adaptive immunity. Nat Rev Immunol 2013;13:510-518.

[18] Haraldsson MK, Louis-Dit-Sully CA, Lawson BR, Sternik G, Santiago-Raber ML, Gascoigne $\mathrm{NR}$, et al. The lupus-related Lmb3 locus contains a disease-suppressing Coronin-1A gene mutation. Immunity 2008;28:40-51.

[19] Shiow LR, Paris K, Akana MC, Cyster JG, Sorensen RU, Puck JM. Severe combined immunodeficiency (SCID) and attention deficit hyperactivity disorder (ADHD) associated with a coronin-1A mutation and a chromosome 16p11.2 deletion. Clin Immunol 2008.

[20] Foger N, Rangell L, Danilenko DM, Chan AC. Requirement for coronin 1 in T lymphocyte trafficking and cellular homeostasis. Science 2006;313:839-842.

[21] Mueller P, Liu X, Pieters J. Migration and homeostasis of naive T cells depends on coronin 1mediated prosurvival signals and not on coronin 1-dependent filamentous actin modulation. $\mathrm{J}$ Immunol 2011;186:4039-4050. 
[22] Mueller P, Massner J, Jayachandran R, Combaluzier B, Albrecht I, Gatfield J, et al. Regulation of $\mathrm{T}$ cell survival through coronin-1-mediated generation of inositol-1,4,5trisphosphate and calcium mobilization after T cell receptor triggering. Nat Immunol 2008;9:424-431.

[23] Jayachandran R, Sundaramurthy V, Combaluzier B, Mueller P, Korf H, Huygen K, et al. Survival of mycobacteria in macrophages is mediated by coronin 1-dependent activation of calcineurin. Cell 2007;130:37-50.

[24] Bosedasgupta S, Pieters J. Inflammatory stimuli reprogram macrophage phagocytosis to macropinocytosis for the rapid elimination of pathogens. PLoS Pathog 2014;10:e1003879.

[25] Didichenko SA, Segal AW, Thelen M. Evidence for a pool of coronin in mammalian cells that is sensitive to PI 3-kinase. FEBS Lett 2000;485:147-152.

[26] Vinet AF, Fiedler T, Studer V, Froquet R, Dardel A, Cosson P, et al. Initiation of multicellular differentiation in Dictyostelium discoideum is regulated by coronin A. Mol Biol Cell 2014;25:688-701.

[27] Suo D, Park J, Harrington AW, Zweifel LS, Mihalas S, Deppmann CD. Coronin-1 is a neurotrophin endosomal effector that is required for developmental competition for survival. Nat Neurosci 2014;17:36-45.

[28] Combaluzier B, Mueller P, Massner J, Finke D, Pieters J. Coronin 1 is essential for IgMmediated $\mathrm{Ca} 2+$ mobilization in $\mathrm{B}$ cells but dispensable for the generation of immune responses in vivo. J Immunol 2009;182:1954-1961.

[29] Westritschnig K, BoseDasgupta S, Tchang V, Siegmund K, Pieters J. Antigen processing and presentation by dendritic cells is independent of coronin 1. Molecular immunology 2013;53:379-386.

[30] Arandjelovic S, Wickramarachchi D, Hemmers S, Leming SS, Kono DH, Mowen KA. Mast cell function is not altered by Coronin-1A deficiency. Journal of leukocyte biology 2010;88:737-745.

[31] Charan S, Zinkernagel RM. Antibody mediated suppression of secondary IgM response in nude mice against vesicular stomatitis virus. J Immunol 1986;136:3057-3061.

[32] Siegmund K, Lee WY, Tchang VS, Stiess M, Terracciano L, Kubes P, et al. Coronin 1 is dispensable for leukocyte recruitment and liver injury in concanavalin A-induced hepatitis. Immunol Lett 2013;153:62-70.

[33] Gatfield J, Albrecht I, Zanolari B, Steinmetz MO, Pieters J. Association of the Leukocyte Plasma Membrane with the Actin Cytoskeleton through Coiled Coil-mediated Trimeric Coronin 1 Molecules. Mol Biol Cell 2005;16:2786-2798.

[34] Nedela V. Methods for additive hydration allowing observation of fully hydrated state of wet samples in environmental SEM. Microsc Res Tech 2007;70:95-100.

[35] Marcais A, Viel S, Grau M, Henry T, Marvel J, Walzer T. Regulation of Mouse NK Cell Development and Function by Cytokines. Front Immunol 2013;4:450.

[36] Combaluzier B, Pieters J. Chemotaxis and phagocytosis in neutrophils is independent of coronin 1. J Immunol 2009;182:2745-2752.

[37] Foger N, Jenckel A, Orinska Z, Lee KH, Chan AC, Bulfone-Paus S. Differential regulation of mast cell degranulation versus cytokine secretion by the actin regulatory proteins Coronin1a and Coronin1b. J Exp Med 2011;208:1777-1787.

[38] Moshous D, Martin E, Carpentier W, Lim A, Callebaut I, Canioni D, et al. Whole-exome sequencing identifies Coronin-1A deficiency in 3 siblings with immunodeficiency and EBVassociated B-cell lymphoproliferation. J Allergy Clin Immunol 2013;131:1594-1603.

[39] Bauer S, Groh V, Wu J, Steinle A, Phillips JH, Lanier LL, et al. Activation of NK cells and T cells by NKG2D, a receptor for stress-inducible MICA. Science 1999;285:727-729.

[40] Narni-Mancinelli E, Vivier E, Kerdiles YM. The 'T-cell-ness' of NK cells: unexpected similarities between NK cells and T cells. Int Immunol;23:427-431.

[41] Zwirner NW, Fuertes MB, Girart MV, Domaica CI, Rossi LE. Cytokine-driven regulation of NK cell functions in tumor immunity: role of the MICA-NKG2D system. Cytokine Growth Factor Rev 2007; 18:159-170.

[42] Mace EM, Orange JS. Lytic immune synapse function requires filamentous actin deconstruction by Coronin 1A. Proc Natl Acad Sci U S A 2014;111:6708-6713. 


\section{Figure Legends}

\section{Figure 1: Frequency and number of NK cells in coronin 1-deficient mice}

Lymphocytes isolated from spleen, liver and blood were stained for NK1.1 and CD3 $\varepsilon$ and analyzed by flow cytometry. A. Representative FACS dot-plots of NK cell frequencies in spleen, liver and blood of wild type and coronin 1-deficient mice. B. Frequencies of NK cells in spleen, liver and blood. C. Absolute NK cell numbers in spleen, liver and blood. Absolute numbers were calculated from the lymphocyte counts per organ determined using a Neubauer counting chamber and the NK frequencies obtained by flow cytometry. Statistical analyses were performed using the non-parametric two tailed Mann-Whitney test $(* * \mathrm{p}<0.01$; $\mathrm{p}<0.05)$. Each symbol represents data of an individual mouse, mean values and SEM are indicated.

\section{Figure 2: Phenotype of wild-type and coronin 1-deficient NK cells}

NK cells from spleen of wild-type and coronin 1-deficient mice were enriched by negative selection and analyzed for expression of actin, coronin 1 and CD122 (IL2R $\beta$ ) by flow cytometry. Note that coronin 1-deficient mice express eGFP driven by the coronin 1 promoter. A. FACS dot-plots of pre-enriched and enriched NK cells (by negative selection) stained with anti- NK1.1 and analyzed for Alexa Fluor 647 and FITC. B. Lysates of enriched NK cells were separated on $10 \%$ SDS gel and blotted against actin and coronin 1. C. Enriched NK cells ( $\sim 65-70 \%$ purity) from wild-type and coronin 1-deficient mice mixed 1:1 were adhered on poly-L-lysine-treated cover slips, stained for actin (Alexa Fluor 637, blue) and coronin 1 (Alexa Fluor 568, red) and analyzed by confocal microscopy. D,E. CD122 expression on NK1.1+ cells from spleens (gated on CD3 $\varepsilon$ negative lymphocytes). 
Representative FACS dot blots are shown. The bar graph depicts the mean fluorescence intensity (MFI) of CD122 expression on NK cells.

Figure 3: Stimulation of activating NK cell receptors of wild-type and coronin 1-deficient NK cells

Splenocytes from wild type or coronin 1-deficient mice were stimulated with plate-bound antibodies. A. Representative FACS gating strategy. B-E: IFN $\gamma$ production (B,C) and CD107a surface exposure (D,E) of wild type and coronin 1-deficient NK-cells was analyzed by flow cytometry after 4.5 hours stimulation by plate bound antibodies against the activating NK cell receptors NK1.1, NKp46, Ly49D and NKG2D. For NKG2D, splenocytes were left untreated (0 hours) or additionally cultured for 20 hours with IL-2 (10 ng/ml; IL2 + 20 hours) prior to stimulation with plate-bound anti-NKG2D $(10 \mu \mathrm{g} / \mathrm{ml})$ coated plate. Statistical analyses were performed using the non-parametric two tailed Mann-Whitney test $(* \mathrm{p}<0.03)$. Error bars represents the SEM.

Figure 4: Cytotoxic activities of coronin 1-deficient NK cells against YAC-1 cells Splenocytes from spleens of wild-type or coronin 1-deficient mice were co-cultured with $5 \times 10^{4} \mathrm{Cr}-51$ radio-labeled YAC-1 cells at the indicated effector:target ratio. Cytoxicity was measured in a 4.5 hours Cr-51-release assay. The graph depicts the mean and SEM of four independent experiments with two mice per group. 


\section{Figure 5 Effect of IL-15 on coronin 1-deficient NK cells}

NK cells from wild-type and coronin 1-deficient mice treated with IL-15 for the indicated time were analyzed for expansion, expansion and morphology. A. NK cells were enriched from spleen and cultured $\left(1-2 \times 10^{5}\right)$ for 21 days in medium supplemented with recombinant IL-15 (10 ng/ml). At the indicated time points, cells were harvested and counted by flow cytometry using counting beads. B. Enriched NK cells were expanded for seven days with IL$15(10 \mathrm{ng} / \mathrm{ml})$ and analyzed by scanning electron microscopy. NK cell purity (measured by NK 1.1 and CD3) at day 7 was up to $99 \%$. C. Splenocytes were isolated and the frequencies of NK cells in the spleen of wild-type and coronin 1-deficient mice were measured by FACS analysis. Equal numbers of wild type and coronin 1-deficient NK cells (as determined based on the frequency and the indicated effector:target (E:T) ratio) were stimulated with IL-15 (10 $\mathrm{ng} / \mathrm{ml}$ ) or medium alone (mock) for 20-22 hours. Cr-51 radio-labeled YAC-1 cells $\left(5 \times 10^{4}\right)$ were then added to the splenocytes and cytoxicity was measured in a 4.5 hours Cr-51-release assay (pooled data from two independent experiments).

\section{Figure 6: NK cell activation after VSV-INDG infection in vivo}

Coronin 1-deficient and wild-type mice were infected with $5 \times 10^{5}-5 \times 10^{6}$ PFU VSV-INDG i.v. or injected with medium alone (mock). After 48 hours, splenocytes and intrahepatic liver lymphocytes (IHL) were isolated and cultured for 4 hours in the presence of brefeldin A. Cells were subsequently stained for NK1.1, CD3 $\varepsilon$ and intracellular interferon- $\gamma$ and analyzed by flow cytometry. A. Representative FACS dot-plot of splenocytes and IHL from VSVinfected or medium-treated ice are shown. B. Total NK cell numbers in the spleen and liver. C. Frequency of interferon- $\gamma$ producing NK cells in the spleen and liver. D. Absolute number of interferon- $\gamma$ producing NK cells after VSV infection. Absolute NK cell numbers were 
calculated from FACS data. Symbols indicate individual mice (gray symbols, $5 \times 10^{\wedge} 6 \mathrm{PFU}$, black/white $\left.5 \times 10^{\wedge} 5 \mathrm{PFU}\right)$. Horizontal bars indicate the mean of 2-4 mice per group. 


\section{Figure 1}

A

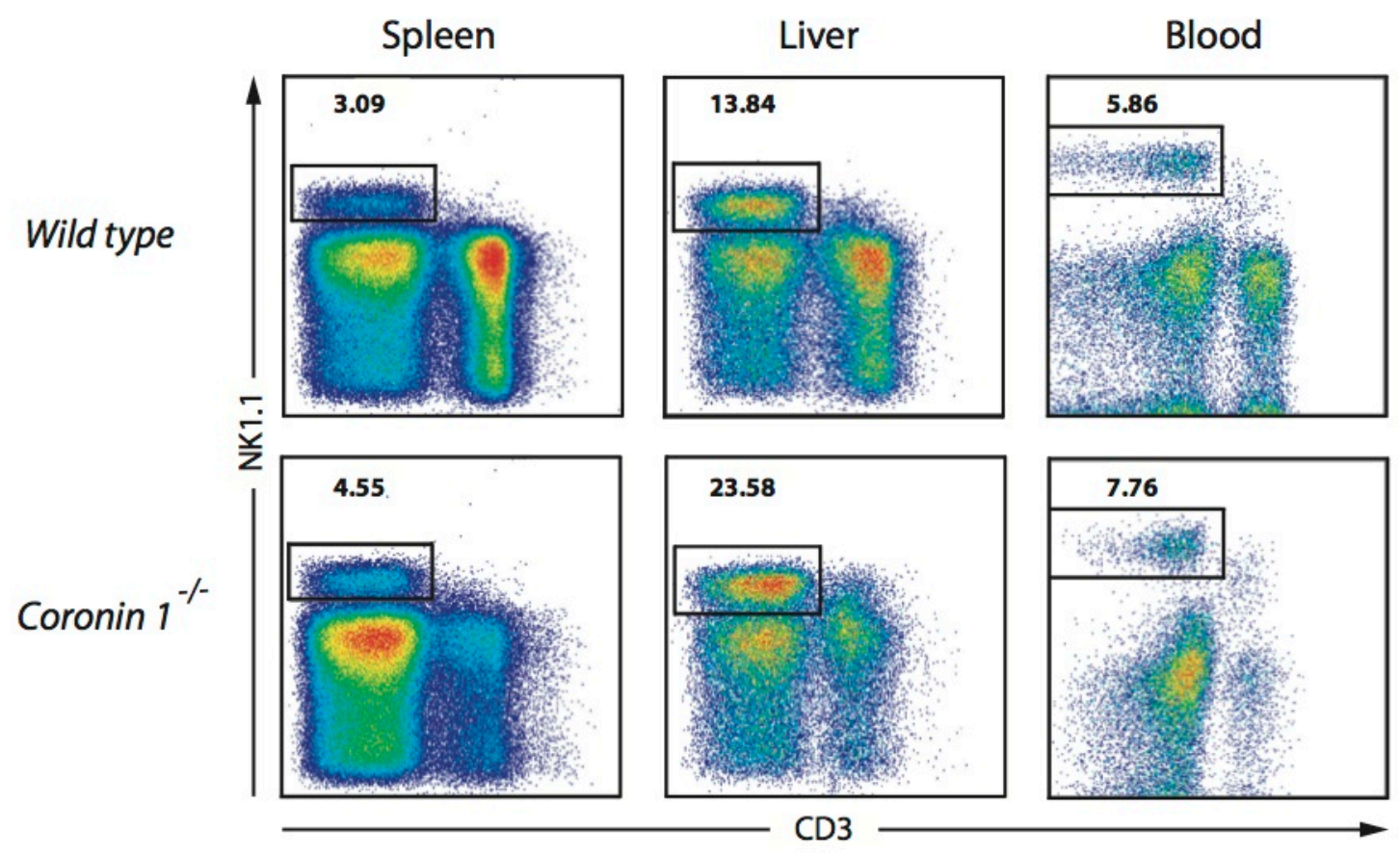

B
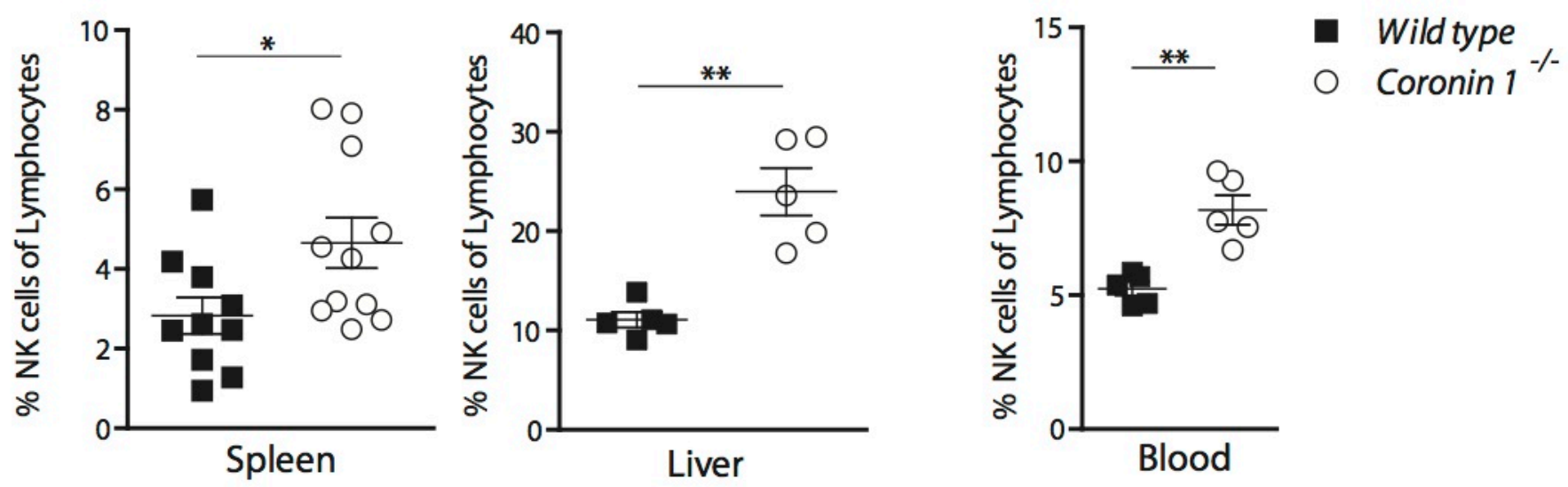

C
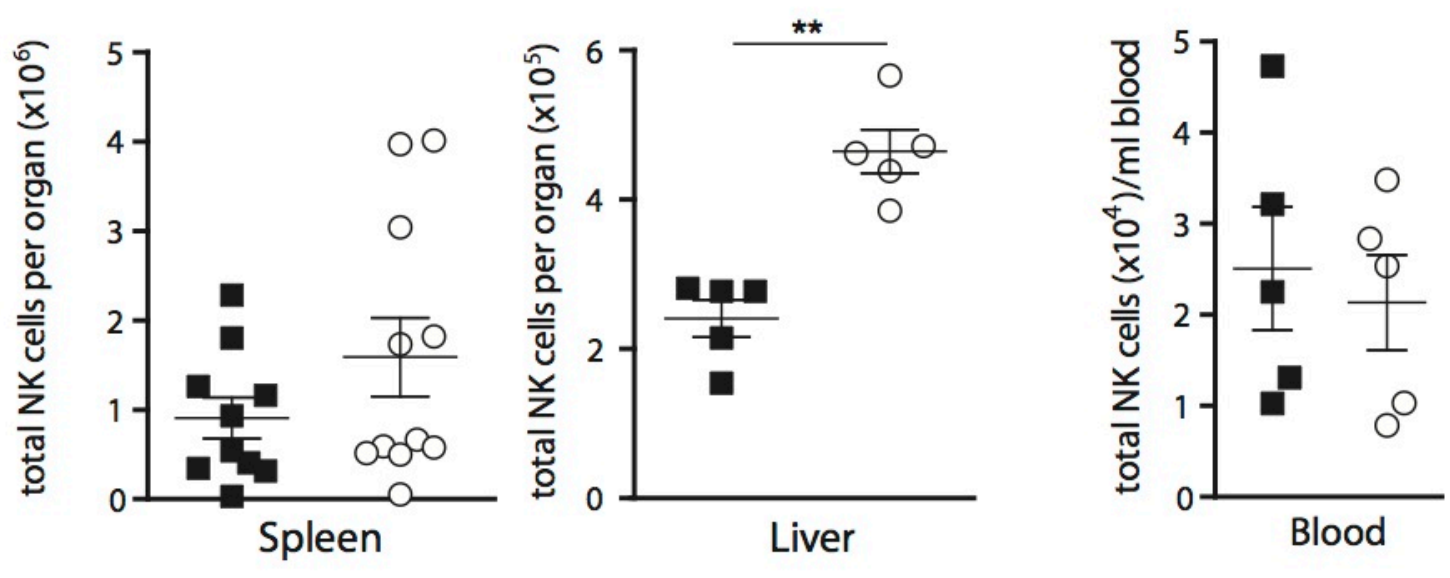


\section{Figure 2}

A

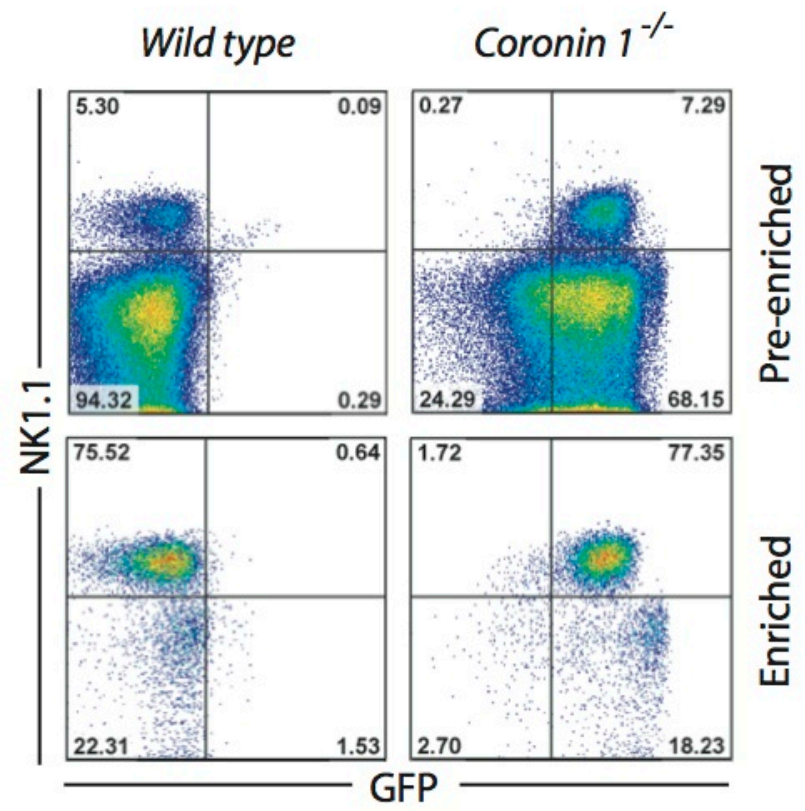

C
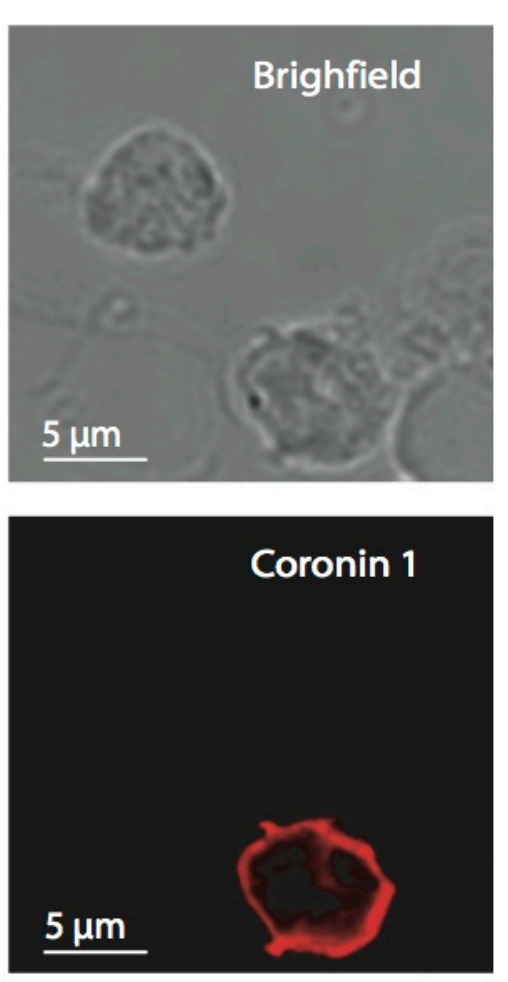

\section{$5 \mu \mathrm{m}$}

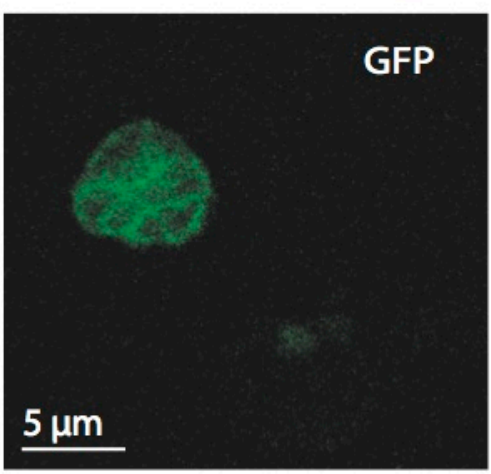

D

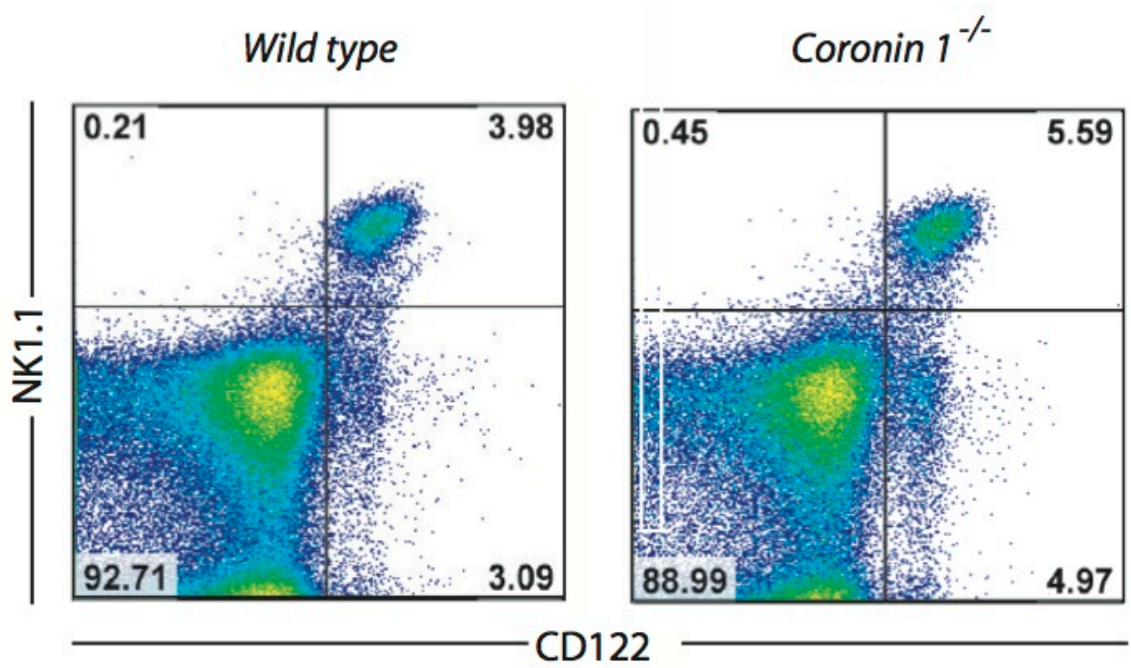

B

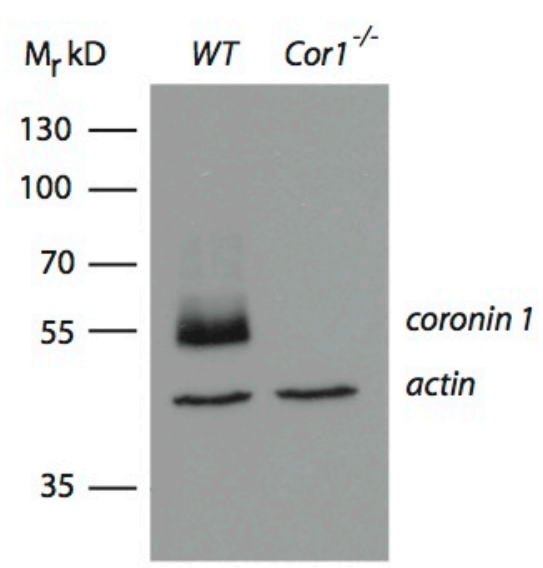

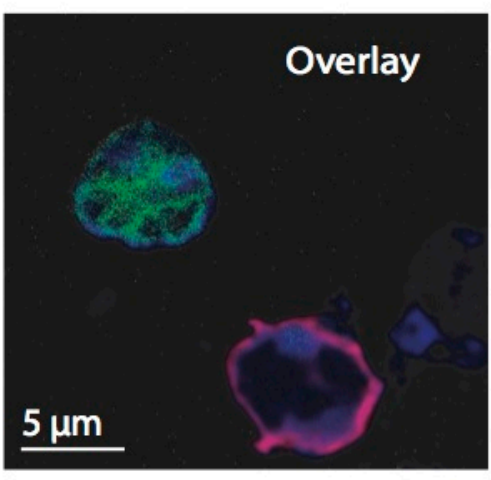

E

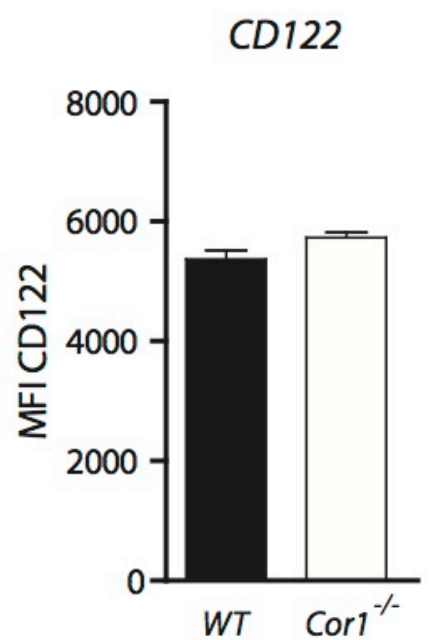

Tchang et al. 
Figure 3

A

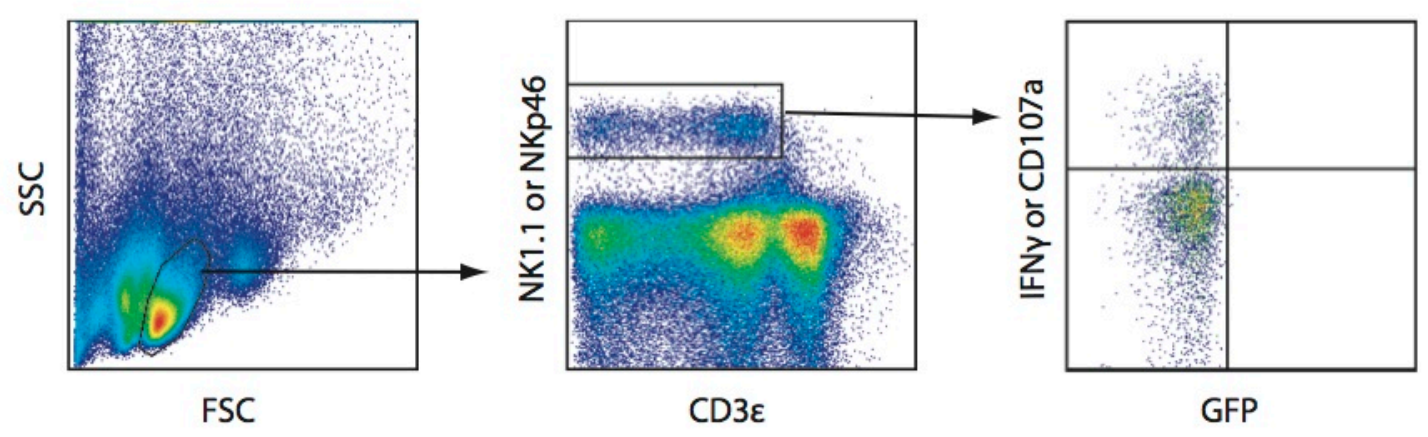

B

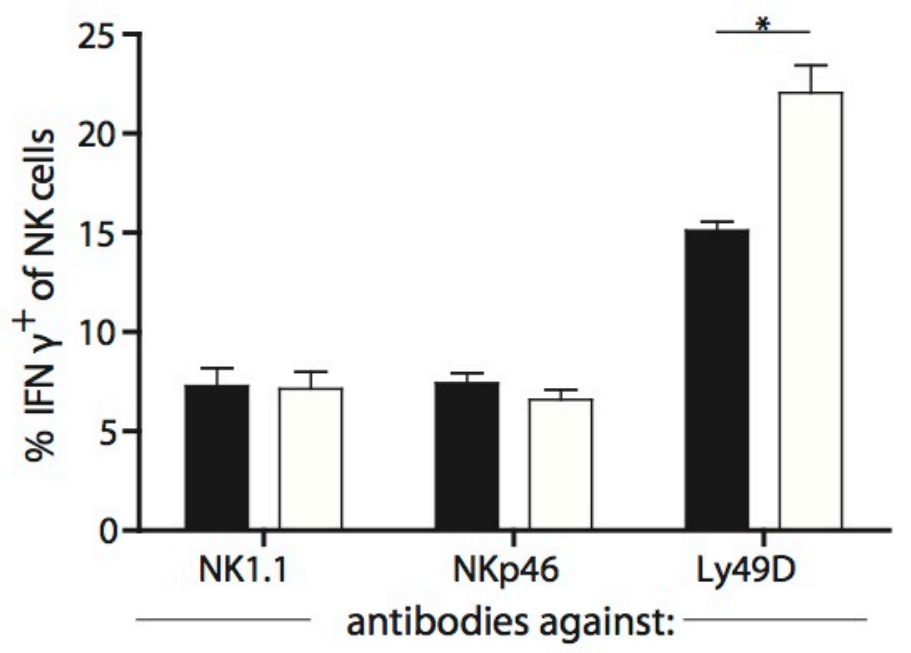

D

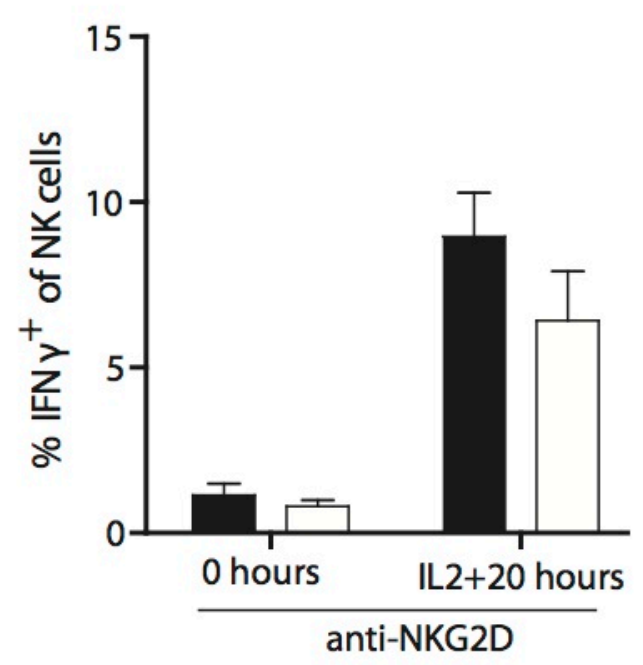

E
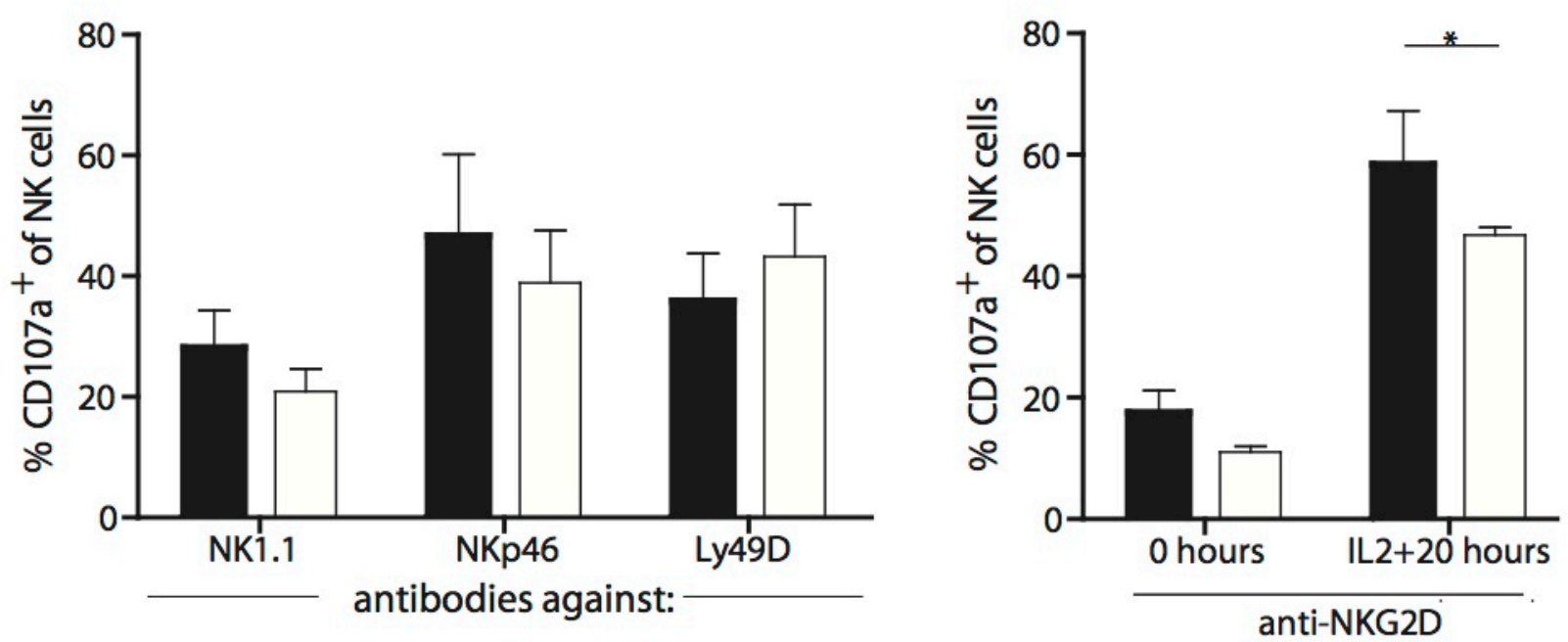
Figure 4

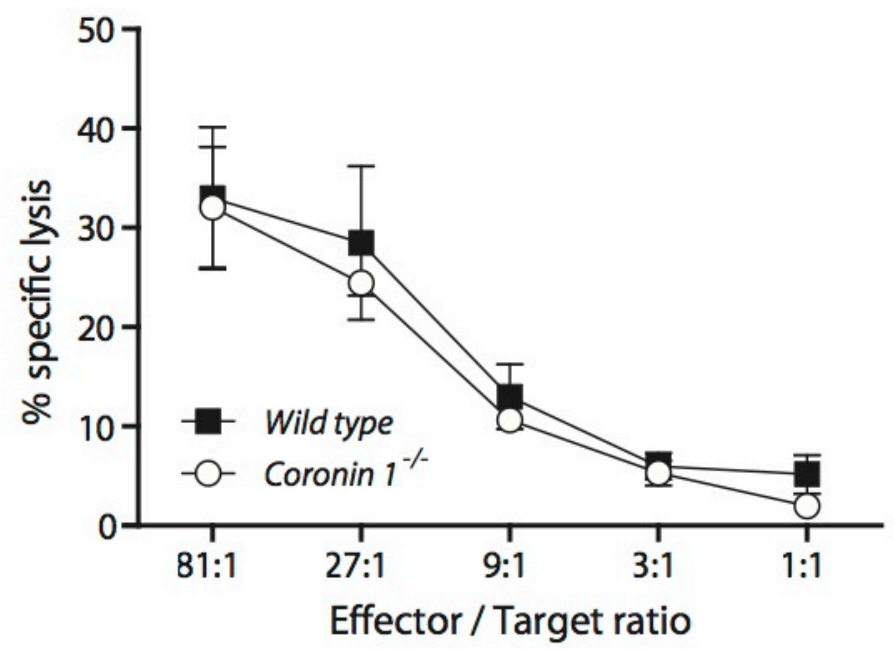

Tchang et al. 
Figure 5

A

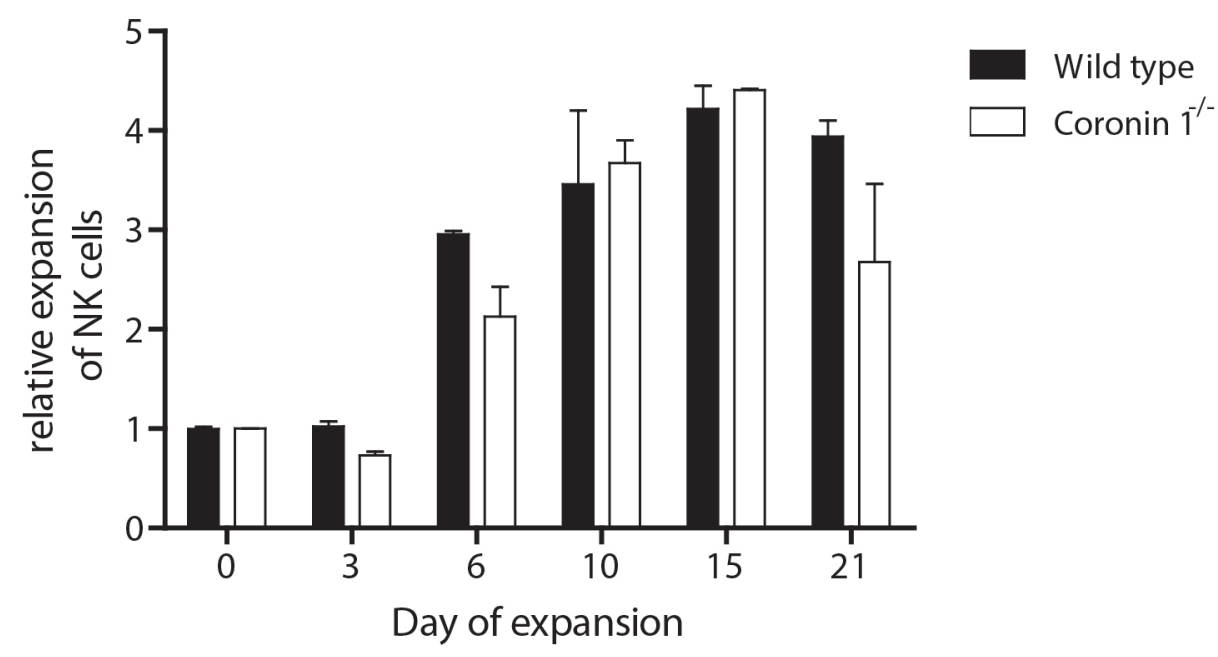

B

Wild type

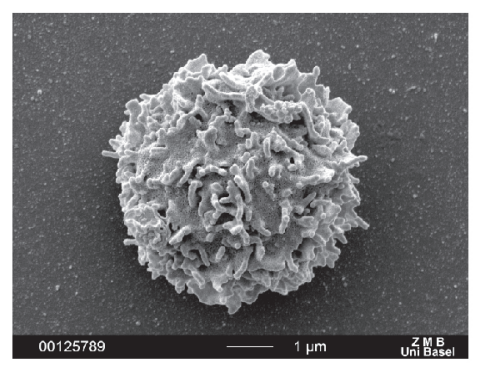

Coronin $1^{-/-}$

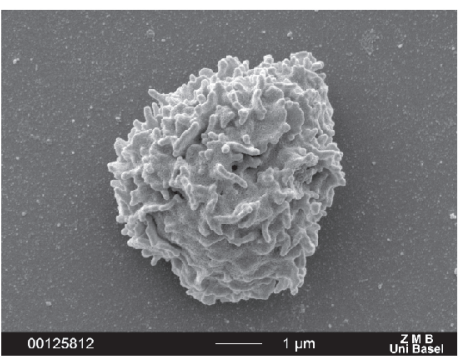

C

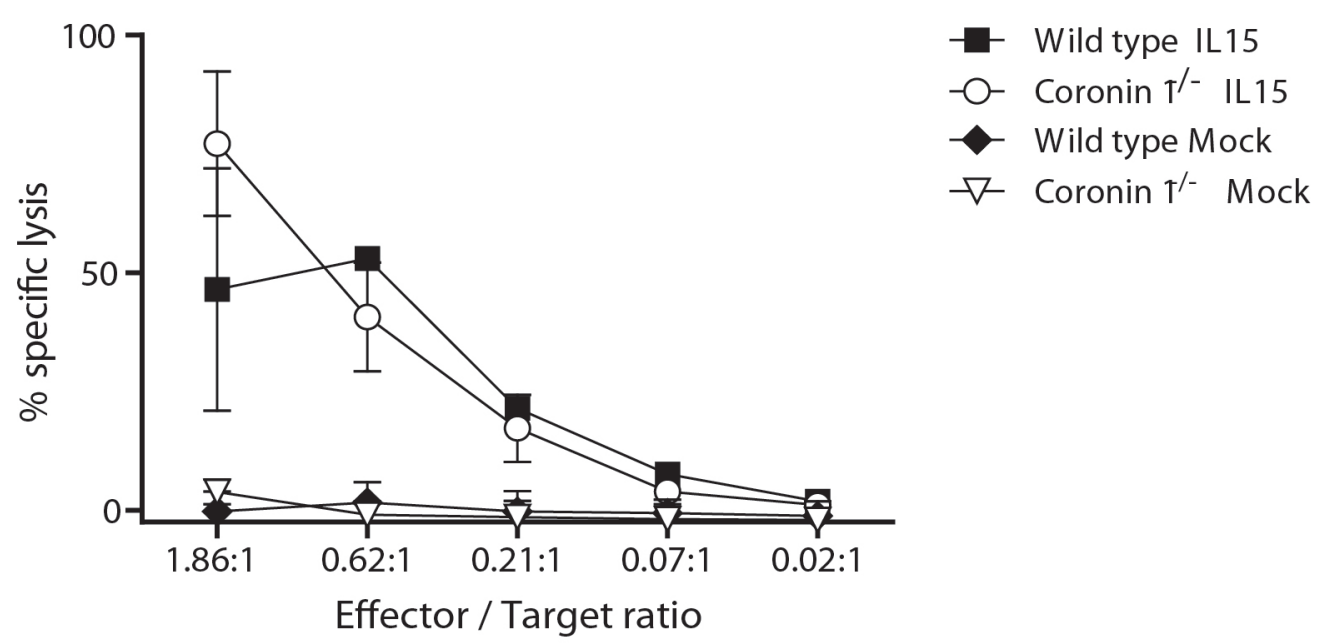

Tchang et al. 
